\title{
FOREIGN LANGUAGE TEACHING TO LINGUISTICALLY GIFTED STUDENTS: COMMUNICATIVE COMPETENCE
}

Gulnara V. Gali, Anastasiya V. Fakhrutdinova, Askar I. Gali

Candidate of Pedagogics Sciences, Kazan Federal University, Kazan, Russia.

Email: gulnaragali@mail.ru

Article History: Received on $15^{\text {th }}$ July 2019, Revised on $30^{\text {th }}$ August 2019, Published on $18^{\text {th }}$ September 2019

\begin{abstract}
Purpose of the Study: The urgency of the problem under investigation is due to the fact that the issue of gifted students' education is one of the most difficult and interesting aspects of contemporary pedagogy. The purpose of the article is to comprehensively characterize the components of foreign language teaching to linguistically gifted students.
\end{abstract}

Methodology: New directions of teaching linguistically gifted students of non-linguistic directions, based on the communicative and personal-activity approach, are analyzed.

Results: In this article, the concept of foreign language competence of students is defined and the content, forms, methods and means of pedagogical interaction in the process of foreign language teaching to gifted students are considered. The authors pay special attention to foreign language teaching to linguistically gifted students.

Applications: The materials of the article can be useful for teachers, students and a wide range of readers interested in the problems of gifted students' education.

Keywords: university, learning, gifted students, foreign language competence, linguistic giftedness.

\section{INTRODUCTION}

In modern domestic and foreign pedagogical science and educational practice, training and education of gifted students are often viewed as a global pedagogical task. Today, the problem of teaching gifted students is directly connected with the new conditions and requirements of a rapidly changing world. The new information society puts forward new challenges for the education system, as intellect and creativity become the main productive and creative force of civilization (Gali, Shakhnina, Zagladina, Belyaeva, Dulmukhametova, \& Ibragimova, 2018). It is obvious that in modern conditions it is necessary to solve the problem of developing of the educational content for gifted students, which promotes the development of creative individuality of students. It should be noted that the educational content for gifted students has a number of differences from the educational content of the majority of their "normal" peers. According to the domestic researcher R. Sagitova, "it is necessary to improve the content of education to solve the problem of the individualization of education" (Sagitova, R.R. (2014).

It is important to note that training gifted students implies, first of all, scientifically grounded training of teachers who are ready to solve the whole complex of issues related to this field. Teachers face a problem while identifying students with outstanding mental capabilities: what and how to teach, how to contribute to their optimal development (Davis \& Rimm, 2004; Taylor, 2000). Of course, the success of training and development of gifted students implies that the teacher has his own concept of activity oriented towards the intellectual and creative development of such students. It is obvious that the work specific of a teacher who educates gifted students determines higher demands on him or her than an ordinary teacher (Callahan, 2001). It cannot be denied that there are some problematic moments in the education of the gifted students - the weakening of scientific and methodological support for teachers working with this category of students, lack of preparation of teachers for individualizing education, psychological and pedagogical support for gifted ones, and also helping gifted parents (Robinson, Shore, \& Enersen, 2007; Watts \& Watts, 1993).

The aim of the article is to reveal the work specifics in the process of foreign language teaching to linguistically gifted students of non-linguistic directions.

\section{METHODOLOGY}

The objects of our investigation are: 1) to define the concept of foreign language competence of students; 2) to determine the content, forms, methods and means of pedagogical interaction in the process of foreign language teaching to gifted students; 3) to study the international experience of working with gifted students to enhance the effectiveness of gifted students' education.

For confirmation of the hypothesis we need to turn to a variety of methods: 
- The method of historical and logical analysis of regulatory documents of foreign governments and research papers of leading scientists connected with educational issues of gifted students' education;

- Study and theoretical analysis and synthesis of social, political and psycho-pedagogical literature;

- Analysis, comparison, synthesis and generalization of innovative foreign and domestic pedagogical experience;

- Comparison of data of foreign and domestic research on this issue.

The fundamental works of foreign and Russian scientists in the field of pedagogy and psychology (J. Frimen, D. Parker, J. Renzulli, E. Torrens, V.I. Andreev, D.B. Bogoyavlenskaya, N.S. Leytes, A.M. Matyushkin V.I. Panov, A.I. Savenkov, F.L. Ratner, etc.) were the theoretical basis of the study.

The usage of the methodology and methods of existing research contributes to the development of scientific thought in education for gifted students. It provides the opportunity to comprehensively address the problem of gifted students' education.

\section{RESULTS}

It should be noted that nowadays the specifics of teaching in universities have changed due to the requirements for the formation of the level of practice-oriented knowledge, foreign language communicative skills, professional and personal qualities of future specialists (Fakhrutdinova \& Kondrateva, 2016). In addition, students' proficiency in a foreign language implies a level of knowledge of a foreign language that allows them to use it to meet their professional needs, realize personal business contacts and further professional self-education that are in demand in the context of the integration of the international educational space.

The interest of researchers to the study of foreign language competence is associated with the transition of higher education from a qualifying approach to a competence-based one, with a reorientation of the evaluation of the educational result from the concepts of "knowledge and skills" to the concepts of "competence". It is also associated with a transition from the qualification model of a specialist focused on the object and the subject of labor to competence-oriented subject of labor (Winebrenner, 2000; Betts \& Kerscher, 1999).

Having analyzed the scientific literature on the research problem, we came to the conclusion that along with the term "foreign language competence," the synonymous concept "foreign language communicative competence" is widely used. So, according to N. Proschyants, foreign language competence is understood as "a set of sociocultural, linguistic knowledge, skills and abilities, implemented by the subject adequately communicative task in a foreign language environment. As a basic concept, foreign language competence can be considered as a system of interacting elements, such as linguistic, linguocultural, sociocultural, professional foreign language, and communicative competence "(Proshyants, $\underline{2010) \text {. }}$

According to G. Bogin, N. Gez, there are levels of development of foreign language competence, which reflect the actual linguistic component of foreign language competence:

- The level of correctness (the ability of a person to use the existing active vocabulary in combination with the correct application of the word);

- The level of interiorization (the communicator has a holistic view of the utterance being made);

- The level of saturation (involves the wide use of a variety of language tools, the absence of primitive vocabulary and syntax in use);

- The level of adequate choice (assurance of a variety of linguistic means in accordance with the context and the specific situation);

- The level of adequate synthesis (which reflects the development of a single linguistic personality) (Bogin, 1984; Gez, 1985).

A foreign researcher J. Raven expands this concept, including a number of components in its composition:

- Linguistic (knowledge of vocabulary, phonetics, grammar and corresponding skills);

- Sociolinguistic (reflects the sociocultural conditions of language use);

- Pragmatic (involves the implementation of the communicative function, the generation of speech acts) (Raven, 2002).

The analysis of the scientific literature shows that foreign language competence is viewed by researchers as a complex, multi-component education, with the professional orientation of foreign language competence of future specialists in the language training process. Researcher O. Galustyan identifies the following components of foreign language competence: 
- Operational - effective component (the ability to implement professional communication in a foreign language in the professional sphere);

- Cognitive component (professional and linguistic knowledge acquired in the course of learning a foreign language);

- Motivational - value component (degree of representation of professionally significant motives and values for learning a foreign language);

- Reflective component (mastering methods of self-analysis, self-esteem in the process of foreign language professionally oriented communication);

- Emotional-volitional component (the ability to self-regulate in the field of professional activity and foreign language professional communication, the ability to overcome the psychological barrier in foreign language communication) (Galustyan, 2008).

In this regard, the interest of foreign language teachers in new areas of study for linguistically gifted students in nonlinguistic areas based on the communicative and personal-activity approach is justified. According to M. Rumyantseva, linguistic talent is defined as an increased level of abilities for accelerated thinking processes in a foreign language, for active cognitive activity in the theory and history of a language, for creativity in choosing ways of communicating in a foreign language, for sustainable motivation in learning a language (Rumyantseva, 2006, p. 15).

Speaking about the linguistic talent of students, it is necessary to single out such a component as linguistic creativity. The linguistic creativity of students is understood as "a set of abilities to create objectively and subjectively new ideal products using native and / or foreign language, producing oral and written statements based on divergent thinking with students' desire for creative speech activity" (Tyuleneva, 2012, p. 5).

According to research V. Panfilova, linguistic giftedness is understood as individual psychological personality, characterized by an increased level of intellectual, linguistic and communicative abilities, providing sustainable motivation in learning a foreign language, speed and ease of acquiring linguistic knowledge, speed of a language learning, creativity in the choice of communication methods in a foreign language, the effectiveness of using a foreign language in the process of professionally oriented foreign language communication (Panfilova, 2015).

Therefore, forming foreign language competence of linguistically gifted students implies the choice and realization of the possibilities of content, forms, methods and means of pedagogical interaction in the process of a foreign language teaching. It is building of a didactic developing environment. The content, forms and methods of work should include an optimal educational space for active, free and creative self-development of linguistically gifted students, ensuring the variability and openness of the educational process, which allows the students the freedom to choose educational and professional foreign language activities (Panfilova, 2015).

Speaking of linguistically gifted students, it should be noted that educational and professional foreign language activities aim at the formation of foreign language competence of linguistically gifted students and implemented in both, classroom and extracurricular forms of education. In the classroom form of education for linguistically gifted students, active group forms of study are used in combination with individual search and research activities in a foreign language. They are such forms as projects, role-playing games, working with electronic dictionaries, using ICT (including working with Internet resources and working in phono laboratories), presentations, contests, quizzes, web quests, problem situations, discussions. Interactive forms allow a teacher to organize active interaction of all participants in the educational process, the exchange of authentic professionally important information in a foreign language and acquire the skills of professional communication, during which the students improve their skills of unprepared speech, the ability to listen to the opinions of others, offer solutions to problems and develop instructions for new creative tasks. Integration of forms and methods of work allows a teacher to simultaneously develop various types of speech activities: speaking, reading, writing and listening. This provides a solution to communication problems in the use of grammar, lexical forms, which allows the students to master linguistic material and speech activity, thereby ensuring the development of various types of foreign language competence.

The most interesting for linguistically gifted students are assignments including the method of "round table" and discussions, since these methods are a kind of dialogue, which includes the principle of collective discussion of the problem, the ability to combine elements of evidence and convictions in the course of the discussion. The students learn to accurately express their thoughts during the discussion, actively defend their point of view in reports and speeches, reasonably express or refute the erroneous position of the opponent (Clasen \& Clasen, 1995).

Out-of-class forms of education, ensuring the formation of foreign language competence, are implemented through creative and intellectual competitions and scientific conferences. 
An important condition in the process of the formation of foreign language competence of linguistically gifted students is the organization of independent work of students. By independent work of students, we understand such educational and professional activities, which are aimed at solving practice-oriented and research tasks of mastering foreign language competence by performing specific learning tasks under the guidance of a teacher. Independent work of linguistically gifted students includes the following forms of work: creative and research projects, blitz-surveys, essays, abstracts and presentations with messages and reports on professional-oriented topics in practical classes, educational Internet resources, participation in forums and electronic seminars and educational projects.

\section{DISCUSSION}

The basic reason to make a detailed analysis of foreign language teaching to linguistically gifted students is to consider the content, forms, methods and means of pedagogical interaction in the process of foreign language teaching to linguistically gifted students of non-linguistic directions. The research has shown that the problem is considered as one of the most important in the world. Various aspects of this problem are reflected in the scientific work of foreign researchers: J. Kagan (2011), A. Passow (2009), J. Whitemore (2012), J. Renzulli (1982) and others. This problem was also considered by Russian researchers: V.A. Andreev (2010), B.L. Wolfson (2003), A.N. Dzhurinskiy (1999), V.I. Panov (2003), A.I. Savenkov (2000), F.L. Ratner (2009), G. Bogin, N. Gez and others. However, analysis of scientific papers on this issue showed us that the problem of linguistic abilities is one of the most complex and still not sufficiently studied.

\section{SUMMARY}

In the course of investigating of this problem, the authors came to the following conclusion: the foreign language competence of linguistically gifted students is understood to be an integrative personality-professional education that determines the student's ability and readiness for creatively solving practice-oriented and informational - communicative tasks in the field of professional activity and foreign-language professional-oriented communication. The following structural components are distinguished:

- Linguistic (proficiency in vocabulary, grammar, phonetics, spelling);

- Discursive (acquisition of connectedness, logical organization of speech and written texts);

- Colloquial (the ability to speak coherently, without tension, at a natural pace, without prolonged pauses to search for language forms when receiving and transmitting professional information);

- Pragmatic (the ability to convey communicative content in accordance with the social context);

- Information technology (the ability to search for foreign language professionally relevant information using various sources and use foreign language information resources of the Internet in the process of professional activity);

- Strategic (the ability to use verbal and non-verbal professional communication strategies to compensate for missing knowledge in the context of real language communication);

- Sociocultural (knowledge of the sociocultural context in which language is used, the ability to build foreign language professional communication adequately with these features);

- Personal-creative (the ability to improve the level of a foreign language knowledge and the ability to selfdevelopment in the process of independent search and creative activity) (Bogin, 1984).

\section{CONCLUSION}

Thus, the problem of linguistic abilities is one of the most complex and still not sufficiently studied.

In this regard, scientists differently determine the linguistic abilities underlying the linguistic talent:

- as "individual psychological personality characteristics characterizing the speed and ease of acquiring linguistic knowledge, ensuring the speed of language acquisition and the effectiveness of language use in the communication process";

- as "a complex education that allows them mastering foreign language speech activity at the expense of basic cognitive mental processes and motivational and personal qualities of a person";

- as "special abilities to master a foreign language, which are a combination of individual psychological qualities of the students' intellect and their personality, determining ease of learning the material and its use in speech activity in a foreign language" ( Shibkova, 2000, p.166].

All this allows us to conclude that the formation of foreign language competence of linguistically gifted students is largely determined by how to build the learning process, by what forms and methods to involve students in educational and professional foreign language activities. The content, forms and methods of work should provide for an optimal educational space for active, free and creative self-development of linguistically gifted students, ensuring the variability and openness of 
the educational process, which allows the student the freedom to choose educational and professional foreign language activities.

\section{AKNOWLEDGEMENT}

The work is performed according to the Russian Government Program of Competitive Growth of Kazan Federal University.

\section{REFERENCES}

1. Betts, G., \& Kerscher, J. (1999). Autonomous learner model: Optimizing ability. Greeley, CO: Autonomous Learning Publications and Specialists.

2. Bogin, G.I. (1984). The model of linguistic personality in its relation to the varieties of texts (Doctoral dissertation). Leningrad.

3. Callahan, C. (2001). Evaluating learner and program outcomes in gifted education. In F.A. Karnes \& S.M. Bean (Eds.), Methods and materials for teaching the gifted (pp. 253-300). Waco, TX: Prufrock Press.

4. Clasen, D. R., \& Clasen, R. E. (1995). Underachievement of highly able students and the peer society. Gifted and Talented International, 10, 67-76. https://doi.org/10.1080/15332276.1995.11672824

5. Davis, G., \& Rimm, S. (2004). Education of the gifted and talented (5th ed.). Boston, MA: Allyn and Bacon.

6. Fakhrutdinova, A.V., \& Kondrateva, I.G. (2016). Modeling Teacher's Multicultural Identity through Studying a Foreign Language: Proceedings of the IFTE 2016 - 2nd International forum on teacher education, 12, 245-250.

7. Gali, G., Shakhnina, I., Zagladina, E., Belyaeva, E., Dulmukhametova, G., \& Ibragimova, A. (2018). The Specificity of Gifted Students' Teaching: Overseas Data: Proceedings of INTCESS 2018- 5th International Conference on Education and Social Sciences, Istanbul, Turkey, 5-7 February (pp.25-31).

8. Galustyan, O.V. (2008). Pedagogical technology of monitoring of the formation of the foreign language communicative competence of students of a non-linguistic university (Doctoral dissertation). Voronezh.

9. Gez, N.I. (1985). Formation of communicative competence as an object of methodological research. Foreign languages at school., 2, 17-23.

10. Panfilova, V.M. (2015). Psychological and pedagogical conditions of the formation of foreign language competence of linguistically gifted students of a non-linguistic university (Doctoral dissertation). Yelabuga.

11. Proshyants, N.A. (2010). Formation of foreign linguistic competences in professional discourse. Research work, 3 , 34-38.

12. Raven, J. (2002). Competence in modern society: Identification, development and implementation. Translation from English. Moscow.

13. Robinson, A., Shore, B., \& Enersen, D. (2007). Best Practices in gifted education: An evidence-based guide. Waco, TX: Prufrock.

14. Rumyantseva, M.V. (2006). Teaching a foreign language of linguistically gifted schoolchildren in the context of additional education (Doctoral dissertation). St. Petersburg.

15. Sagitova, R.R. (2014). Training students to be autonomous learners. International Journal of Humanities Education, 12, 27-34. https://doi.org/10.18848/2327-0063/CGP/v12i01/43817

16. Shibkova, O.S. (2000). Diagnostics and the formation of cognitive components of the linguistic abilities of high school students with in-depth study of the English language (Doctoral dissertation). Stavropol.

17. Taylor, S. (2000). Assessment and evaluation. Retrieved September 15, 2003.

18. Tyuleneva, T.V. (2012). Formation of linguistic creativity of students of non-linguistic specialties (Doctoral dissertation). Volgograd.

19. Watts, M., \& Watts, D. (1993). Teacher research, action research: The logo action research collaborative. Educational Action Research, 1(1), 35-63. https://doi.org/10.1080/0965079930010104

20. Winebrenner, S. (2000). Gifted students need an education, too. Educational Leadership, September, 52-56. 